\title{
ТЕОРЕТИЧНИЙ АНАЛІЗ ПСИХОЛОГІЧНИХ ОСОБЛИВОСТЕЙ ПЕРФЕКЦІОНІЗМУ У ЮНАЦЬКОМУ ВІЦІ Марчук Сніжана
}

Вінницький державний педагогічний університет імені Михайла

Коцюбинського, м. Вінниця, Україна

kucheryava_snizhana@ukr.net

ORCID-ID: 0000-0001-8530-3702

Мета. У статті розкрито теоретичний аналіз психологічних особливостей перфекціонізму у юнацькому віці. Мета статті полягає в теоретичному аналізі психологічних особливостей перфекціонізму у юнацькому віці.

Методи. В основу дослідження покладено теоретичні методи: аналіз, синтез та узагальнення наукових джерел із проблем вивчення перфекціонізму та психологічних особливостей юнацького віку.

Результати. До результатів належить теоретичний аналіз базових позицій вивчення перфекціонізму в осіб юнацького віку. Представлено огляд досліджень різних науковців до причин виникнення перфекціоністських тенденцій. Стаття містить опис деяких вікових особливостей виникнення i розвитку перфекціонізму. Проведений аналіз наукової літератури вказує на те, що батьки мають істотний вплив на розвиток перфекціонізму у дітей. Доведено, що проблема перфекціонізму досить нова в українській науковій літературі, i наявність потреби дослідження перфекціонізму вимагає більш глибокого аналізу цього феномену на сучасному етапі розвитку психологічної науки в Україні. Також стаття містить детальний опис психологічних особливостей періоду юнацтва, зокрема, новоутворень у юнацькому віці та кризи ідентичності. Описані окремі індивідуально-типологічні передумови розвитку перфекціонізму. Зазначено актуальність вивчення перфекціонізму саме в юнацькому віці. У статті визначено, що кожен тип перфекціонізму має вплив на формування особистості юнаків. Ступінь вираженості кожного типу перфекціонізму в юнацькому віці $\epsilon$ різним. Констатовано, що найбільш представленим є високий рівень перфекціонізму, орієнтованого на себе в осіб юнацького віку.

Висновки. У висновках зазначено, що перфекціонізм як психологічний феномен має значний вплив на формування особистості. Для юнацького віку $є$ характерними завищені вимоги до себе, тому юнаки вважають, що оточуючі пред'являють їм завищені вимоги. Відповідно до наукових досліджень, високий рівень перфекціонізму, орієнтованого на себе, найбільш характерний для осіб юнацького віку.

ISSN 2308-3743 (Online), ISSN 2227-1376 (Print)

(C) Марчук C., 2021. Ця стаття відкритого доступу на умовах CC BY-NC 4.0 
Ключові слова. Прагнення до досконалості, юнаки, сім'я, особистість, суб’єкт, діяльність, вплив.

\section{Marchuk Snizhana. Theoretical analysis of psychological features of} perfectionism in adolescence.

Purpose. The purpose of the article is a theoretical analysis of the psychological features of perfectionism in adolescence.

Methods. The study is based on theoretical methods: analysis, synthesis and generalization of scientific sources on the problems of studying perfectionism and psychological features of adolescence.

Results. The results include a theoretical analysis of the basic positions of the study of perfectionism in adolescents. An overview of research by various scientists on the causes of perfectionist tendencies is presented. The article describes some age features of the origin and development of perfectionism. The analysis of the scientific literature indicates that parents have a significant influence on the development of perfectionism in children. It is proved that the problem of perfectionism is quite new in the Ukrainian scientific literature, and the need to study perfectionism requires a deeper analysis of this phenomenon at the present stage of development of psychological science in Ukraine. The article also contains a detailed description of the psychological features of adolescence, in particular, neoplasms in adolescence and identity crisis. Some individual-typological preconditions of development of perfectionism are described. The relevance of the study of perfectionism in adolescence is noted. The article defines that each type of perfectionism has an impact on the formation of young people's personality. The severity of each type of perfectionism in adolescence is different. It is stated that the most represented is a high level of self-centered perfectionism in adolescents.

Conclusions. The conclusions indicate that perfectionism as a psychological phenomenon has a significant impact on the formation of personality. Adolescence is characterized by excessive demands on themselves, so young people believe that others make excessive demands on them. According to scientific research, a high level of self-centered perfectionism is most characteristic of adolescents.

Keywords. Striving for perfection, young people, family, personality, subject, activity, influence.

\section{Марчук Снежана. Теоретический анализ психологических} особенностей перфекционизма в юношеском возрасте.

Цель. В статье раскрыт теоретический анализ психологических особенностей перфекционизма в юношеском возрасте. Цель статьи состоит в теоретическом анализе психологических особенностей перфекционизма в юношеском возрасте.

Методы. В основу исследования положены теоретические методы: анализ, синтез и обобщение научных источников по проблемам изучения перфекционизма и психологических особенностей юношеского возраста. 
Результаты. К результатам принадлежит теоретический анализ базовых позиций изучения перфекционизма у лиц юношеского возраста. Представлен обзор исследований различных ученых к причинам возникновения перфекционистских тенденций. Статья содержит описание некоторых возрастных особенностей возникновения и развития перфекционизма. Проведенный анализ научной литературы указывает на то, что родители оказывают существенное влияние на развитие перфекционизма у детей. Доказано, что проблема перфекционизма является достаточно новой в украинской научной литературе, и наличие потребности исследования перфекционизма требует более глубокого анализа данного феномена на современном этапе развития психологической науки в Украине. Также статья содержит подробное описание психологических особенностей периода юношества, в частности, новообразований в юношеском возрасте и кризиса идентичности. Описаны отдельные индивидуально-типологические предпосылки развития перфекционизма. Указано на актуальность изучения перфекционизма именно в юношеском возрасте. В статье определено, что каждый тип перфекционизма влияет на формирование личности юношей. Степень выраженности каждого типа перфекционизма в юношеском возрасте является различным. Констатировано, что наиболее представленным является высокий уровень перфекционизма, ориентированного на себя у лиц юношеского возраста.

Выводы. В выводах отмечается, что перфекционизм как психологический феномен имеет значительное влияние на формирование личности. Для юношеского возраста характерны завышенные требования к себе, потому юноши считают, что окружающие предъявляют им завышенные требования. Согласно научным исследованиям, высокий уровень перфекционизма, ориентированного на себя, является наиболее характерным для лиц юношеского возраста.

Ключевые слова: стремление к совершенству, юноши, семья, личность, субъект, деятельность, влияние.

Вступ. Інноваційне суспільство XXI століття характеризується динамічним розвитком соціальних, економічних, політичних аспектів, а особистість, яка $є$ невід'ємною частиною його, має відповідати йому високими стандартами 3 усіх сторін. Активно розвиваючись, навколишнє середовище висуває значну кількість вимог до певних якостей та рис особистості, що сприятимуть іiі успішній життєдіяльності. Зараз, на сучасному етапі розвитку людства, вагому роль відіграє саме суб'єкт, тобто особистість, яка повинна бути різнобічно та гармонійно розвиненою, сприяти інноваціям, легко адаптуватися до нових умов, що висуває 
суспільство. Важливим є також прагнення до самоактуалізації. I характеристикою такого суб'єкта є особистісно зріла людина.

На сучасному етапі розвитку психологічної науки все більше викликає інтерес науковців феномен перфекціонізму. Адже протягом тривалого часу він є предметом багатьох емпіричних досліджень, і вивчення його спричинено багатьма чинниками. Саме поняття «перфекціонізм» (з лат. перекладається як «абсолютна досконалість») розглядають не тільки в психологічному аспекті, але й у філософському, етичному, соціальному та інших аспектах пізнання. Та все ж таки надзвичайно важливим $є$ питання про вплив перфекціонізму на особистість, адже одні вчені акцентують увагу на позитивному впливі цього феномену, інші - навпаки.

Вивчення вікових аспектів перфекціонізму - важливий напрям дослідження для психологічної науки, і взагалі суспільства в цілому. Адже визначення механізмів та закономірностей його впливу на життєдіяльність молодої людини надасть можливість отримати відповіді на багато запитань, які протягом тривалого часу хвилюють і психологів, і психіатрів, і соціологів. Досліджень вікових аспектів перфекціонізму на сучасному етапі розвитку світової психології надзвичайно мало. Найголовнішою причиною, на нашу думку, є те, що сам феномен перфекціонізму, механізми і закономірності його виникнення вивчені недостатньо. Це актуальний вектор дослідження сьогодення не тільки українських науковців, а й зарубіжних також.

Мета презентованого матеріалу полягає в теоретичному аналізі психологічних особливостей перфекціонізму в юнацькому віці.

Методи та процедура дослідження. В основу дослідження покладено теоретичні методи: аналіз, синтез й узагальнення наукових джерел із проблем вивчення перфекціонізму та психологічних особливостей юнацького віку.

Обговорення результатів. Термін «перфекціонізм» психологічна наука визначає як прагнення до досконалості, яке стосується як особистості, так і результатів будь-якої діяльності (Гаранян, 2006: 32). Вчені вважають, що перша згадка поняття «перфекціонізм» 3'явилася в працях американського науковця М. Холлендера 1965 року. Науковець визначав перфекціонізм перш за все як рису особистості, що характеризується пред'явленням до себе більш високих вимог, ніж того вимагають обставини (Hollender, 1965). 
Саме дослідження канадських учених П. Хюітта і Г. Флетта дали поштовх до вивчення перфекціонізму як багатовимірного феномену, адже в його структуру включили три параметри (Hewitt, 1991). Перший - «Я»-адресованний перфекціонізм, який характерний для осіб, що ставлять для себе високі особистісні стандарти, схильні до постійного самооцінювання і цензурування своєї поведінки. Такий перфекціонізм поєднує як афективні, так і мотиваційні поведінкові компоненти. Другий - перфекціонізм, адресований іншим людям. Особи з таким перфекцінізмом мають завищені очікування щодо значимих людей, очікують від інших досконалості та їх постійно оцінюють. Третій - соціально запропонований перфекціонізм, характерний для людей, яким властиві переконання в тому, що інші люди схильні дуже строго оцінювати і вимагати від усіх досконалості (Гаранян, 2009: 79). Три параметри, які були виділені, покладено в основу Багатовимірної шкали перфекціонізму, яку розробили науковці. Зазначений опитувальник дозволив розглянути феномен перфекціонізму різнобічно. По-перше, з точки зору самої особистості, а по-друге - значущих інших і соціального середовища.

Науковець Є. Ільїн вважає, що перфекціоністські орієнтації починають формуватися ще в молодшому шкільному віці. Передумови виникнення закладені в сімейному вихованні і пов'язані 3 оціночною любов'ю у вигляді схвалення чи несхвалення дитячої поведінки. Тому дитина прагне бути досконалою, звичайно, щоб уникнути несхвалення з боку батьків. Проте з іншого боку, дитина прагне до відчуття того, що вона є важливою і цінною для дорослих через схвалення. Автор також зазначає, що найчастіше перфекціоністами стають діти, які є одними в батьків. Якщо ж сім'я багатодітна, до старших дітей висувають жорсткіші вимоги та щодо них мають високі очікування (Ильин, 2011).

Основними помилками в сімейному вихованні, на думку Є. Ільїна, які спричиняють розвиток перфекціонізму в дітей, є: орієнтація на пошук лише правильних способів у навчанні, іграх, вирішенні поставлених завдань; різка критика за помилки та невдачі; демонстрація любові тільки з приводу успіхів та досягнень; указівка на постійну перевірку своєї діяльності для уникнення помилок. Діти 3 такою тактикою сімейного виховання прагнуть до уникнення невдач, ставлять перед собою завищені цілі, відчувають себе потрібними лише за умови ідеальної діяльності та ін. Науковці стверджують, що 
оцінювання дітей лише за успіхи закріплюється у подальшому у вигляді шкільних оцінок, які можуть призводити до формування «комплексу відмінника» i спричинятимуть постійне переживання стресу у зв’язку з прагненням до успішної навчальної діяльності (Вьюнова, 2015).

Турецький психолог Ц. Фатіх досліджував зв'язок перфекціоністських тенденцій учнів середньої школи та їхніх батьків. За результатами дослідження науковець зробив висновок, що на розвиток перфекціонізму у дітей мають вплив перфекціоністські тенденції, що проявляються як і в батька, так і в матері (Fatih, 2009). Такі результати, спираючись на теорію А. Бандури, засвідчують, що особистість дитини формується в соціальному середовищі. Найбільший досвід дитина отримує під час спостереження за поведінкою інших, особливо це стосується значимих для дітей дорослих, у тому числі і батьків. Так, дитина намагається робити все ідеально, імітуючи поведінку батьків, яку вона спостерігає. Модель зв'язку перфекціонізму дітей 3 перфекціонізмом їхніх батьків інтерпретується через ставлення батьків до дітей i наслідування батьків, які є взірцями.

Дж. Стобер i К. Отто також вивчали питання виникнення перфекціонізму. Вони досліджували вплив батьківського перфекціонізму на перфекціонізм у дітей. Науковці побачили, що діти, які демонстрували високий рівень перфекціоністських тенденцій, мали батьків, яким був притаманний такий же рівень. I такий зв’язок посилювався, коли досліджувані діти і батьки з рисами перфекціонізму були одної статі. Було зроблено висновок, що наслідування моделей поведінки батьків відіграє роль у розвитку позитивних проявів перфекціонізму( Stober, 2006).

Дослідники стверджують, що на розвиток перфекціонізму найбільший вплив має мотивація досягнення успіху, мотивація уникнення невдач, локус контролю, конформізм, тривожність, самооцінка. Проте 3 часом інтенсивність впливу та кількість зазначених особистісних чинників знижується; максимальна взаємозумовленість перфекціонізму й особистісних властивостей має місце в підлітковому віці через найбільшу чутливість до перфекціоністських вимог, стійкість до яких виявляється 3 дорослішанням (Кононенко, 2015). 
Науковець I. Гуляс, вивчаючи перфекціоністські настанови, виділила аспект: формування перфекціоністських настанов відбувається під впливом мотивації досягнення i прагненням до неперевершеності. І. Гуляс поняття «перфекціонізм» визначає перш за все як готовність особистості до прагнення до успіху i досконалості у важливих для неї ситуаціях (Гуляс, 2007).

3 огляду на психологічну специфіку юнацького віку, особливої уваги заслуговує дослідження перфекціонізму саме в цей віковий період. Тоді, коли юнакам властива постановка високих, а іноді і завищених цілей, з одного боку, і недостатня особистісна зрілість, 3 іншого. Період юності у психології визначається як психологічний вік переходу до самостійності, період самовизначення, формування психічної, ідейної та громадянської зрілості, формування світогляду і самосвідомості. Психологами виділено ранню юність (від 15 до 18 років) і пізню юність (від 18 до 23 років) (Засєкіна, 2013). Важливою характеристикою юності $\epsilon$ психологічна готовність до дорослого життя, тому в юнаків гостро зароджуються потреби у взаємодії 3 іншими людьми, прагненні до творчості, вмінні орієнтуватися у різноманітних подіях, розвиненій рефлексії. Це характеризує суть новоутворень раннього юнацького віку, якими $є$ особистісне та професійне самовизначення (Божович, 2007).

Вікові межі юнацького періоду психологи визначають порізному, проте всі погоджуються 3 тим, що цей період характеризується професійним самовизначенням та формуванням ціннісних орієнтацій. Юнакам властиво переживати почуття «інтимності»; планування кар'єри і залучення у професійне середовище; вироблення здатності до особистісного вибору, вміння виявляти свободу і відповідальність щодо реалізації життєвих цілей і смислів» (Мотрук, 2019: 184).

Загалом юнацький вік $є$ найбільш сприятливим періодом для завершення формування та становлення особистості. Тому в цьому віці основним прагненням особистості $\epsilon$ саморозвиток та самопізнання, а також самореалізація, яка надає особистості можливість здійснення власного потенціалу. Риси особистісної зрілості є наперед важливими для особистості у юнацькому віці (Чепурна, 2009). Підтвердженням, по-перше, $є$ те, що в юнацькому віці остаточно відбувається формування уявлень особистості про себе. Це пов'язано з кризою ідентичності, яка складається з вибору 
соціальних та індивідуально-особистісних, а також з ідентифікацій i самовизначення. Сукупність уявлень надають можливість відчувати свою унікальність і автентичність, що виявляється через Я-концепцію (Леонтьев, 2001). По-друге, обгрунтована значущість рис пропріуму особистісної зрілості для его-ідентичності особистості та відповідність статусу досягнутої его-ідентичності оптимальним показникам особистісної зрілості (Шляпникова, 2010). По-третє, особистісна зрілість як результат формування особистості характеризується як психологічне новоутворення, яке є важливим для его-ідентичності особистості (Штепа, 2008). Саморозуміння тісно пов'язане із самоприйняттям, адже для зрілої особистості це одна 3 найголовніших характеристик. Особистісно зріла людина має гармонійні уявлення щодо самої себе, розуміє відносність власних успіхів та не концентрується на невдачах, не ставить за мету дотримуватися виконання жорстких умов i правил, щоб бути щасливою.

Нинішні дослідження питань перфекціонізму в осіб юнацького віку стосуються проблеми параметрів формування перфекціонізму. Доведено, що $є$ окремі індивідуально-типологічні передумови розвитку перфекціонізму. Одна з таких передумов - високий рівень нейротизму, тому серед осіб юнацького віку 3 високим рівнем перфекціонізму переважають холерики і сангвініки (Ларских, 2015). Мотиваційна сфера також має свої особливості в юнаків, яким притаманний перфекціонізм. Особливо прослідковуються відмінності між конструктивним та неконструктивним перфекціонізмом. Якщо ж переважає перший - домінують мотиви досягнення успіху i самореалізації, другий - мотиви уникнення невдачі, тривожність, низька самооцінка (Вьюнова, 2015). Науковець О. Лоза ототожнює соціально-приписаний перфекціонізм із перфекціоністською самопрезентацією, основою якої є мотивація (Лоза, 2015). Інший погляд на цю тему висловила відома українська дослідниця Г. Чепурна. Вона вважає, що перфекціоністська самопрезентація виступає як мотиваційний компонент соціально-приписаного перфекціонізму (Чепурна, 2015)

Взагалі для юнаків характерно вимагати від себе більше, ніж того потребують обставини, а також вважати, що інші пред’являють їм завищені вимоги. Науковці, вивчаючи зв'язки перфекціонізму матері і перфекціонізму юнаків, не виявили значущості: тип перфекціонізму 
матері не пов'язаний $з$ типом перфекціонізму юнака. Проте методи виховання все-таки мають істотний вплив на формування перфекціонізму (Горская, 2013).

У психології, відповідно до онтопсихологічного підходу, саме свідомий перфекціонізм починає розвиватися в підлітків та юнаків. Тоді в них зароджуються перші думки про себе як про досконалу особистість. Науковець А. Менегетті, вивчаючи аспекти юнацького перфекціонізму, дослідила свідомий перфекціонізм і тлумачить його як впевненість особи у своїй виключній зверхності над іншими. А. Менегетті вважає: якщо юнак не прагне до пошуку самого себе, то він спирається на впевненість своєї переваги над іншими. Також у процесі вивчення перфекціонізму науковцем було введено поняття «критичного ідеалізму», який, на його думку, притаманний талановитим юнакам (Менегетти, 2004). Подібної точки зору додержується дослідник О.Савенков. Він стверджує, що перфекціонізм - один із компонентів обдарованості особистості, i його можна помітити вже в дитинстві (Савенков, 2004).

Досліджуючи ефект перфекціонізму на способи реагування на успіхи чи невдачі інших людей, науковець Т. Бескова дійшла висновку: чим більш виражений перфекціонізм у особистості, тим більше вона помічає переважання інших. I здебільшого способи такого реагування є негативними (Бескова, 2012).

Продовжуючи тему вивчення перфекціонізму в юнацькому віці, науковці Г. Крайг і Д. Бокум у своїй праці «Психологія розвитку» описують, що для юнаків властиве занадто велике захоплення власними почуттями. Інколи вони впевнені в тому, що їхні емоції неповторні і ніхто не відчував подібних почуттів (Крайг, 2011). Егоцентризм підлітків та юнаків має свої певні прояви, і дослідник С. Блатт визначив один із них як персональний міф, який означає відчуття юнаків, що вони особливі. Науковець заявляє, що ці відчуття, ймовірно, є передумовою перфекціонізму, адже підлітки та юнаки мають труднощі 3 усвідомленням того, що їм складно візуалізувати, як звичайні пересічні люди змогли народити унікального індивіда (Blatt, 1982: 234).

Прагнення до саморозвитку в юнаків, як правило, формується під впливом інших людей, які є значимими для них. I це прагнення включає також соціальні нормативи й очікування, які висувають юнакам важливі для них люди. Ідеальне «Я», яке задається 
суспільством, зазвичай має пряму протилежність досвіду і потребам особистості. Адже бувають такі обставини, коли юнаки не усвідомлюють і відповідно не сприймають свої особистісні риси. Тоді саморозвиток стає наслідком неузгодженості «Я-пережитого» і «Ясправжнього». Процеси самовдосконалення здійснюються внаслідок незначного заперечення внутрішнього досвіду. Відповідно неузгодженість проявляється у зниженні задоволеності юнаками самими собою, саме це, можливо, спонукає до самовдосконалення, при цьому наслідком може стати деструктивний перфекціонізм.

Взагалі у юнацькому віці ступінь вираженості кожного типу перфекціонізму $\epsilon$ різним. Найчастіше $\epsilon$ високий рівень перфекціонізму, орієнтованого на себе. Попри те, що науковці П. Хьюїт і Г. Флетт тлумачили Я-орієнтованний перфекціонізм як умовно конструктивний, автори моделі показали, що Я-орієнтований i соціально-приписуваний перфекціонізм має кореляційні зв'язки із симптомами депресії саме в осіб юнацького віку (Hewitt, 1991). Соціально-приписуваний перфекціонізм має низький рівень вираженості. Це свідчить про несуттєвість переконань у тому, що інші люди нереалістичні у своїх очікуваннях або схильні чинити тиск 3 метою прагнення до досконалості. Перфекціонізм, орієнтований на інших, має середній рівень вираженості.

Висновки. Отже, теоретичний аналіз психологічних особливостей перфекціонізму в юнацькому віці засвідчує, що на формування перфекціоністських тенденцій має вплив сімейне виховання, адже зародження їх починає відбуватися у молодшому шкільному віці. Приділено багато уваги саме на проблему критеріїв формування перфекціонізму в юнацькому віці. До них належить рівень нейротизму, мотиви досягнення успіху й уникнення невдач. Адже для юнацького віку характерні завищені вимоги до себе, тому юнаки вважають, що люди, які їх оточують, пред’являють їм завищені вимоги. Згідно 3 науковими дослідженнями, в юнаків переважає високий рівень перфекціонізму, орієнтованого на себе.

Перфекціонізм як психологічний феномен має значний вплив на формування особистості. Наявність низки ще не розкритих питань про вікові аспекти перфекціонізму та особистісні конструкти дає нові актуальні завдання для подальших перспективних досліджень. Перспективи досліджень полягають у детальнішому емпіричному 
вивченні впливу перфекціонізму на різні сфери життєдіяльності осіб юнацького віку.

\section{Література}

1. Божович, Л. (1997). Проблемы формирования личности. «МОДЭК». Воронеж.

2. Бескова, Т. В. (2012). Взаимосвязь перфекционизма со способами реагирования на успех и неудачу другого. Современные проблемы науки $и$ образования, 2.

3. Вьюнова, Н. И. (2015). Обзор исследований, посвященных интерперсональному аспекту перфекционизма. Научно-медицинский вестник Центрального Черноземья, 59, 22-27.

4. Гаранян, Н. Г. (2006). Перфекционизм и психические расстройства (обзор зарубежных эмпирических исследований). Терапия психических расстройств,1, 23-31.

5. Гаранян, Н. Г. (2009). Психологические модели перфекционизма. Вопросы психологии, 5,74-83.

6. Горская, Г. Б. (2013). Перфекционизм родителей и стили родительского воспитания как регуляторы мотивации и тревожности юных шахматистов 7-11 лет. Физическая культура, спорт - наука и практика, 3, 5155 .

7. Гуляс, I. А. (2007). Перфекціоністські настанови як чинник професійної готовності майбутніх практичних психологів. Автореф. дис. на здобуття наук. ступеня канд. псих. наук. Івано-Франківськ.

8. Засєкіна, Л.В.(2013). Психолінгвістика, мовленнєва діяльність, особистість: співвідношення понять у контексті мовленнєвої генези дитини. Гуманітарний вісник Переяслав-Хмельнищького державного педагогічного університету імені Григорія Сковороди, 15, 83-85.

9. Ильин, Е. (2011). Работа и личность. Трудоголизм, перфекиионизм, лень. Питер.

10. Кононенко, O. I. (2015). Гендерні особливості проявів перфекціонізму особистості. Вісник ОНУ імені I. I. Мечникова. Серія «Психологія», 2 (36), 99-105.

11. Крайг, Г. (2011). Психология развития. Питер.

12. Ларских, М. В. (2015). Индивидуально-типологические детерминанты перфекционизма студента. Известия Воронежского государственного педагогического университета, 2 (267), 227-231.

13. Леонтьев, Д. А. (2001) Личностная зрелость как опосредствование личностного роста. Культурно-историческая психология развития, 154-161. Москва: Смысл.

14. Лозаб, О. О. (2015). Особливості перфекціонізму як особистісної риси державних службовців. Дис. канд. псих. наук. Київ. 
15. Менегетти, А. (2004). Психология лидера. «Онтопсихология». Москва.

16. Мотрук, Т. О., Вертель, А. В. (2019). Особливості перфекціонізму в юнацькому віці. Актуальні проблеми психології. Психологія обдарованості, 4, 182-192.

17. Савенков, А. И. (2004). Путь к одаренности: исследовательское поведение дошкольников. Питер.

18. Чепурна, Г. Л. (2009). Перфекціонізм як чинник соціальної активності молоді. Вісник Чернігівського педагогічного університету, 74, 172177.

19. Чепурна, Г. Л. (2015). Особливості прояву соціально приписаного перфекціонізму молоді. Вісник Чернігівського національного педагогічного університету. Серія: Психологічні науки, 126, 171-175.

20. Шляпникова, И. А. (2010). Взаимосвязь эго-идентичности и личностной зрелости. Дис. на соискание канд. психол. наук. Челябинск.

21. Штепа, О.С. (2008). Особистісна зрілість. Модель. Опитувальник. Тренінг. Львів.

22. Blatt S. (1982). Dependency and self-criticism: psychological dimensions of depression. Journal of Consulting and Clinical Psychology, 50, 113-124.

23. Fatih, C. (2009). Predicting the students' perfectionism from their parents' perfectionism. Procedia:Social and Behavioral Sciences, 3, 4260-4266.

24. Hewitt, P. (1991). Perfectionism in the Self and Social context: conceptualization, assessment and association with psychopathology. Journal of Personality and Social Psychology, 60 (3), 456-470.

25. Hollender, M. H. (1965). Perfectionism. Comprehensive Psychiatry, 6, 94-103.

26. Stober, J., Otto, R. (2006). Positive Conception of perfectionism. Approaches. Evidence. Challenges. Personality and Social Psychology Rewier, 10, 295-319.

\section{References}

1. Bozhovich, L. (1997). Problemy formirovaniya lichnosti [Personality formation problems]. «MODEK». Voronezh [in Russian].

2. Beskova, T. V. (2012). Vzaimosvyaz' perfektsionizma so sposobami reagirovaniya na uspekh i neudachu drugogo [The relationship of perfectionism to ways of responding to the success and failure of another]. Sovremennyye problemy nauki i obrazovaniya - Modern problems of science and education, 2 [in Russian].

3. V'yunova, N. I. (2015). Obzor issledovaniy, posvyashchennykh interpersonal'nomu aspektu perfektsionizma [A review of research on the interpersonal dimension of perfectionism]. Nauchno-meditsinskiy vestnik Tsentral'nogo Chernozem'ya - Scientific Medical Bulletin of the Central Black Earth Region, 59, 22-27 [in Russian].

4. Garanyan, N. G. (2006). Perfektsionizm i psikhicheskiye rasstroystva (obzor zarubezhnykh empiricheskikh issledovaniy) [Perfectionism and Mental 
Disorders (Review of Foreign Empirical Research)]. Terapiya psikhicheskikh rasstroystv - Therapy for mental disorders, 1, 23-31 [in Russian].

5. Garanyan, N. G. (2009). Psikhologicheskiye modeli pefektsionizma [Psychological models of pefectionism]. Voprosy psikhologii - Psychology issues, 5, 74-83 [in Russian].

6. Gorskaya, G. B. (2013). Perfektsionizm roditeley i stili roditel'skogo vospitaniya kak regulyatory motivatsii i trevozhnosti yunykh shakhmatistov 7-11 let [Parental perfectionism and parenting styles as regulators of motivation and anxiety in young chess players 7-11 years old]. Fizicheskaya kul'tura, sport - nauka $i$ praktika - Physical culture, sports - science and practice, 3, 51-55 [in Russian].

7. Hulyas, I. A. (2007). Perfektsionist-s'ki nastanovy yak chynnyk profesiynoyi hotovnosti maybutnikh praktychnykh psykholohiv [Perfectionist guidelines as a factor in the professional readiness of future practical psychologists]. Extended abstract of candidate's thesis. Ivano-Frankivs'k [in Ukrainian].

8. Zasyekina, L. V. (2013). Psykholinhvistyka, movlennyeva diyal'nist', osobystist': spivvidnoshennya ponyat' u konteksti movlennyevoyi genezy dytyny [Psycholinguistics, speech activity, personality: the relationship of concepts in the context of the speech genesis of the child]. Humanitarnyy visnyk PereyaslavKhmel'nyts'koho derzhavnoho pedahohichnoho universytetu imeni Hryhoriya Skovorody - Humanitarian Bulletin of Pereyaslav-Khmelnytsky State Pedagogical University named after Hryhoriy Skovoroda, 15, 83-85 [in Ukrainian].

9. Ilin, E. (2011). Rabota i lichnost. Trudogolizm, perfektsionizm, len [Work and personality. Workaholism, perfectionism, laziness]. Piter [in Russian].

10. Kononenko, O. I. (2015). Henderni osoblyvosti proyaviv perfektsionizmu osobystosti [Gender features of manifestations of personality perfectionism.]. Visnyk ONU im. I. I. Mechnykova. Seriya Psykholohiya - Bulletin of ONU named after II Mechnikov. Series Psychology, 2 (36), 99-105 [in Ukrainian].

11. Krayg, G. (2011). Psikhologiya razvitiya [Developmental psychology]. Piter [in Russian].

12. Larskikh, M. V. (2015). Individual'no-tipologicheskiye determinanty perfektsionizma studenta [Individual-typological determinants of student perfectionism]. Izvestiya Voronezhskogo gosudarstvennogo pedagogicheskogo universiteta - Izvestiya Voronezh State Pedagogical University, 2 (267), 227-231 [in Russian].

13. Leont'yev, D. A. (2001). Lichnostnaya zrelost' kak oposredstvovaniye lichnostnogo rosta [Personal maturity as a mediation of personal growth]. Kul'turnoistoricheskaya psikhologiya razvitiya - Cultural-historical developmental psychology, 154-161. Moskva: Smysl [in Russian].

14. Loza, O. O. (2015). Osoblyvosti perfektsionizmu yak osobystisnoyi rysy derzhavnykh sluzhbovtsiv [Features of perfectionism as a personal trait of civil servants]. Candidate's thesis. Kyiv [in Ukrainian].

15. Menegetti, A. (2004). Psikhologiya lidera. «Ontopsikhologiya» [Leader psychology. Ontopsychology]. Moskva [in Russian]. 
16. Motruk, T. O., Vertel', A. V. (2019). Osoblyvosti perfektsionizmu v yunats'komu vitsi [Features of perfectionism in adolescence]. Aktual'ni problemy psykholohiyi. Psykholohiya obdarovanosti - Current problems of psychology. Psychology of giftedness, 4, 182-192 [in Ukrainian].

17. Savenkov, A. I. (2004). Put' $k$ odarennosti: issledovatel'skoye povedeniye doshkol'nikov [The Path to Giftedness: Exploratory Behavior in Preschoolers]. Piter [in Russian].

18. Chepurna, H. L. (2009). Perfektsionizm yak chynnyk sotsial'noyi aktyvnosti molodi [Perfectionism as a factor of social activity of youth]. Visnyk Chernihivs'koho pedahohichnoho universytetu - Bulletin of Chernihiv Pedagogical University, 74, 172-177 [in Ukrainian].

19. Chepurna, H. L. (2015). Osoblyvosti proyavu sotsial'no prypysanoho perfektsionizmu molodi [Features of manifestation of socially ascribed perfectionism of youth]. Visnyk Chernihivs'koho natsional'noho pedahohichnoho universytetu. Psykholohichni nauky - Bulletin of Chernihiv National Pedagogical University. Psychological sciences, 126, 171-175 [in Ukrainian].

20. Shlyapnikova, I. A. (2010). Vzaimosvyaz' ego-identichnosti i lichnostnoy zrelosti [The relationship between ego-identity and personal maturity]. Candidate's thesis. Chelyabinsk [in Russian].

21. Shtepa, O. S. (2008). Osobystisna zrilist'. Model'. Opytuval'nyk. Treninh [Personal maturity. Model. Questionnaire. Training]. L'viv [in Ukrainian].

22. Blatt, S. (1982). Dependency and self-criticism: psychological dimensions of depression. Journal of Consulting and Clinical Psychology,50, 113-124.

23. Fatih, C. (2009). Predicting the students' perfectionism from their parents' perfectionism. Procedia: Social and Behavioral Sciences, 3, 4260-4266.

24. Hewitt, P. (1991). Perfectionism in the Self and Social context: conceptualization, assessment and association with psychopathology. Journal of Personality and Social Psychology, 60 (3), 456-470.

25. Hollender, M. H. (1965). Perfectionism. Comprehensive Psychiatry, 6, 94-103.

26. Stober, J., Otto, R. (2006). Positive Conception of perfectionism. Approaches. Evidence. Challenges. Personality and Social Psychology Rewier, 10, 295-319.

Received: 21.04.2021

Accepted: 11.05.2021 